\title{
"Internet +" Epoch Social Management Innovation: Challenge and Response - To the Case of Shanghai Taxi Operations Management
}

\author{
Dan Yang ${ }^{1} \&$ Kai $\mathrm{Yu}^{2}$ \\ ${ }^{1}$ School of Management, Shanghai University Of Engineering Science, Shanghai, China. \\ ${ }^{2}$ School of Social Science, Shanghai University Of Engineering Science, Shanghai, China. \\ Correspondence: Dan Yang, School of Management, Shanghai University Of Engineering Science, Shanghai, China.
}

Received: October 5, 2015

Accepted: October 19, 2015

Available online: October 26, 2015

doi:10.11114/ijsss.v3i6.1172

URL: http://dx.doi.org/10.11114/ijsss.v3i6.1172

\begin{abstract}
Human society has entered the Internet age, the network plays a very important function in all aspects of social management. In recent years, operational management of the taxi industry once again become the focus of the society because of various taxi network software prevalence. Take Shanghai Taxi management model for example, Compare the comparison of traditional and the present stage management mode and measures taken by the government. Summary and analysis the deficiency of the taxi industry and the government management. On this basis, developed the taxi industry how to take the role of the market in public services, how governments use the Internet to integrate the taxi market and improve management and service levels.
\end{abstract}

Keywords: Internet +, Social management innovation, Taxi management model, Public services

\section{Introduction}

Ke-Qiang $\mathrm{Li}$ in his government work reported that "the development of Internet + Action Plan." That "Internet +" action plan foreshadowed the development of the information age to a new, more advanced form - the "Internet + " era. "Internet + " era of the enormous economic and social ideas and behavior change, no doubt on the transformation of government functions presented new challenges. How to respond to these changes, the transformation of government functions have to face and solve the age problem.

Recently, with the degree of social concern taxi operators more and more events, "Internet + " era of the impact in the taxi industry has highlighted. The traditional taxi business model has been difficult to adapt to changing times, resulting in a series intensification of contradictions.

\section{Literature Review}

\subsection{Related concepts carding}

"Internet +", is an innovative development of the Internet under 2.0 new forms, new formats, morphological evolution of the Internet to promote knowledge of social innovation under 2.0. Spawned a new generation of information technology innovation 2.0, 2.0 and innovative action, in turn, formed a new generation of information technology and development patterns, remodeling of Things, cloud computing, social computing, new forms of big data, a new generation of information technology and to further promote the knowledge society to user innovation, open innovation, mass innovation, collaborative innovation is characterized by innovations 2.0, it changed the way we produce, work, lifestyle, also led the development of innovation-driven "new normal."

"Internet + " represents a new era of economic and social form, that is fully optimized and integrated the role of the Internet in the allocation of production factors and social life, the depth of the Internet innovations in the areas of economic and political integration in the society, to enhance the real economy innovation and productivity, optimize the social management functions, the formation of the Internet as a platform and tool for economic and social de velopment to achieve a new form. "Internet +" era of inclusive, timely, open and innovative features, to a certain extent, to subvert the traditional way of life, work and behavior, increasing the complexity of the enormity of the social management.

\subsection{For the study of the internet age in public management innovation}

Development of the Internet exposed and amplified the problems of social management, Party committees and 
governments attach great importance to the impact of social management taken by the development of the Internet, they have take measures to strength social management innovation (Zhu Kun , 2012[19]). At present age of the Internet for innovative research in public administration focused on how to play a positive function of the network, inhibiting its negative features, so as to better promote the social management, government, society and individuals We should make efforts in three areas (Zhang Song-Qun, 2013[17]).

\subsection{For the study of the "Internet + " time taxi operations management}

For the study of taxi operations management from past studies taxi supply and demand conditions, and policies and regulations to this stage focus on the use of network management model to explore, display the taxi network operation background. Cao Yi rally car under software background empty driving taxi trip distribution is analyzed and analyzed in a taxi cab background in software empty driving stage passengers traveling speed and select features probability differences, noted that all the occupants to use the software produced by a taxi taxi trips empty driving total of all the occupants do not use the taxi software $8.9 \%$. In the context of software use a taxi, taxi to get more accurate distribution of passenger demand in the region, so empty driving taxis can carry passengers become possible to live in the district (Cao Yi and Luo Xia , 2015[1]; Cao Yi and Luo Xia , 2014[2]).

Undoubtedly arise taxi software facilitates everyone's needs, whether the market point of view to consider the issue is one of the taxi operators at this stage of the debate. The reform of the monopoly status of the taxi industry is not only the call of the masses, is the general trend. On the market in the end how much the taxi market should have the final say, not the competent authorities shot forehead, do not let vested interests control. "Limousine service" is an innovative way to travel, which originated in the metropolitan transportation supply and demand imbalance is the redistribution of existing community resources, it reflects the shared economic development trend, welcomed by the community. In the comprehensive deepening reform, the rule of law under the overall trend, the authorities to abandon the old management thinking and management style, cut not fall behind in this wonderful era (Sun Ai-Dong, 2015[15]).

Now stage a taxi while the prevalence of software brought "limousine service" and the transport strike event. Integration is the theme of Shanghai taxi market in recent years ( Liu Chang-Rong, 2011[8]). Taxi management to meet the needs of urban development, intensify reform, properly handle the government - the company - a taxi driver - passenger relationship between the interests of the chain. (Yang Fang-Fang, 2014[12]). Taxi operators face a series of problems posed by the Internet, should speed up the legislative work, integrated management functions and strengthen a matter of ex post regulation and industry chain collaboration (Yuan Guang-Xiang, 2014[13]). Government as decision makers and managers should be concerned about the power of citizens from all walks of life as well as bottom-up constraints on the government. Public policy should adhere to scientific and democratic, to improve the quality of policy formulation, to avoid serious argument has not been hastily and hastily introduced, if policies to rush and formality, it will cause the quality of the policy is not high, not only will resulting in difficulty in enforcement policy, but also in the hearts of the people lose confidence in the policy-making bodies and implementing agencies. Therefore, the government taxi management decisions should ultimately listen to the suggestions of the masses.

\section{3. "Internet +" impact on the operation and management of the taxi in Shanghai}

\subsection{The traditional management model taxi operators}
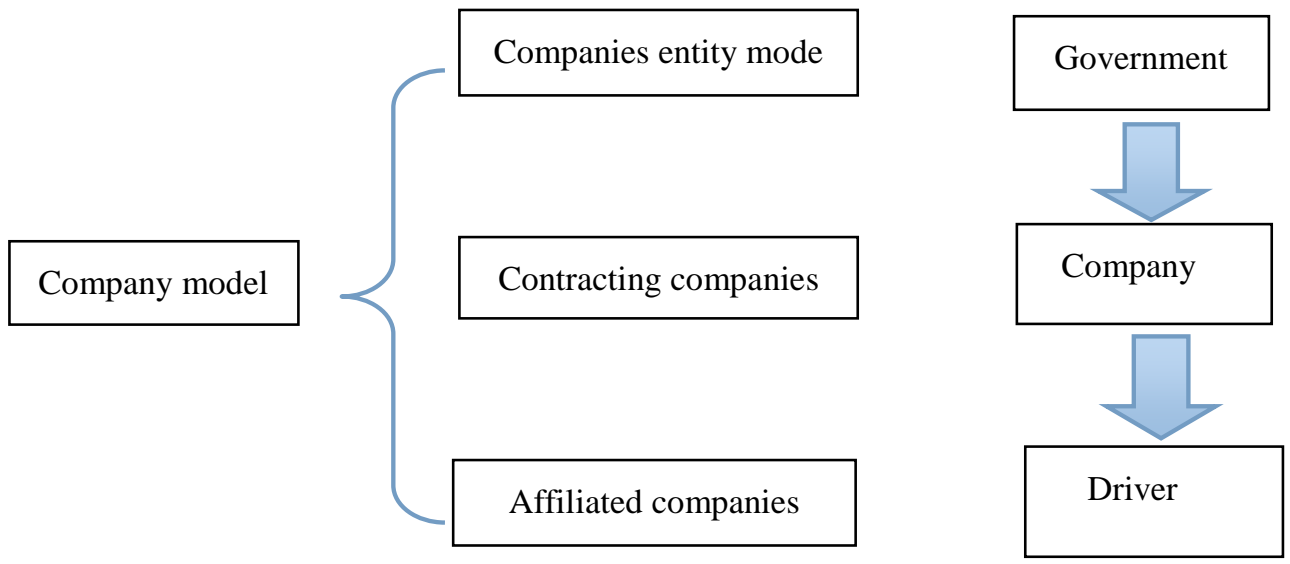


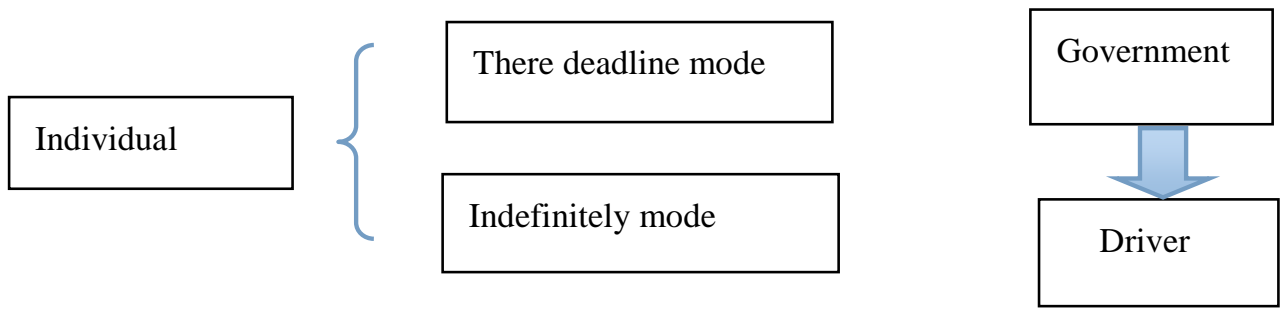

\subsubsection{The company model}

Figure 1

According to figure 1 the company can be summarized into three patterns: solid pattern companies, contracting companies mode, affiliated companies mode. Mode of operation of the company by the government to give the company through free or paid rationing auction, after the company obtained the right to operate, if the entity type, the company hiring drivers, in accordance with the modern enterprise system operate independently; if it is contracted type, the company directly to the driver or subcontractor company the right to operate and vehicles, to charge a deposit, receive copies of money each month.

\subsubsection{Individual mode}

Individual mode, refer taxi ownership and management rights are owned by individuals, the driver or the owner is the main market in the full sense.Individualized model is direct government rationing by free or paid auction, will be given the right to operate individual. Mainly including deadline and indefinite in two ways. Indefinite mode most have a deadline for individual taxi has to affiliated companies transition, such as Taiyuan and other places.

\subsubsection{The Shanghai taxi management model}

Shanghai taxi operator service is positioned as part of the urban public transport, which is defined as between private transport and public transport between the "quasi-public goods." Taxi franchise owned by the government, the implementation of the joint-stock reform, the company's operations. Shanghai, the company's operations while maintaining the gradual optimization system anchored to encourage cooperative management system, to explore the commission system.

\subsection{The changes under the "Internet + " era taxi operation mode}

With the "Internet + " development, a taxi software more and more popular in the taxi industry, taxi drops from the beginning to the present car software uber like. The involvement of the network platform, making Shanghai taxi business model has undergone an obvious change, resulting in a car is different from the traditional model, which makes the traditional company of a great impact on the taxi industry stakeholders are involved from the government, the company, the driver of the three development for the government, companies, drivers and network operators.

\subsection{The practice taken by Shanghai on taxi industry reform}

Shanghai as the country's first and "bit quick" cooperation of local governments, both sides have jointly launched the taxi information service platform, also jointly explore about rental management. At the airport, port, railway station and other important transportation hub, all taxis queuing system by passengers waiting in the designated area, passengers should queue up waiting for customers on the car rental point. Do not use a taxi passenger software, any vehicle can not order maintenance operations order. Since March 2015, Shanghai traffic enforcement Corps joint police department, the lead pilot in Xuhui District "drunk driving mode" Charles car. Held in July 21, Shanghai People's Congress group discussion venue, Shanghai CPPCC members, City Transportation Commission Director Sun Jian-Ping also revealed that the second half will begin the compulsory car purchase third-party liability insurance, and establish complaint channels.

Shanghai Municipal Transportation Commission also noted that they will joint different Department to restrict the network software company, while Shanghai will launch research about car hire, promote network about car specification development and to encourage the integration of mobile Internet and the taxi industry innovation, improve operational service efficiency. However, the network platform about car transport market to comply with the rules, provide legal operation of vehicles, with qualified drivers, safeguard the legitimate rights and interests of passengers. City Transportation Commission will guide cooperation with third-party network platform has qualified passenger transport operators. 


\section{4. "Internet +" time for public management opportunities and challenges}

\subsection{Challenge to management concept}

Internet play between the government and citizens of both an interactive role in the formation of a trust, mutual relations, equality and cooperation. There should be a positive attitude between government and citizens look at the problem, the government should people deemed partnership role. The government should implement the "control" to "management" and "service" concept of change.

\subsection{Challenges to the management system}

New information technology will loose the rights and the rights of decentralized networks, in fact, broke the one-way configuration, centralized monitoring of vertical logic, information power has been decentralized to the computer among millions. Of which a large number of computers not only receive information, but also the production of information, such as Web page. Always, they become fragmented center, not just read, listen and watch the center, but the center of production and broadcasting. Therefore, the "Internet $+"$ era has brought conflict centralization and decentralization, and its essence is a flat management model the impact of the old vertical management.

\subsection{Challenges to the management mode}

\subsubsection{The government crisis management increases}

Since the opening and super regional of the network, newsworthy event of crisis, speculation will be hugely magnified. This allows Crisis management of government departments difficult. For example, in the taxi incident, increasing the participation of citizens, published their views through a variety of network channels, most of the supportive comments on the car.

\subsubsection{Increasing social instability coefficient}

Information networks have to the center, virtual, super regional characteristics, blurring the boundaries of countries and regions, promote the emergence of electronic time and space is difficult to control; at the same time, due to the sharing of information and freedom of expression can be achieved in large part, political participation of the people unprecedented enthusiasm; this will inevitably impact authoritarian centralized management, damage cohesion and all levels of government authoritarian state, which greatly promoted the spread of decentralization and decentralization.

\section{How to deal with the challenges the government to change the "Internet +" time to bring the taxi industry}

\subsection{Change management concepts}

The government should self-diagnosis, summarize experience from work to find their own lack of development of the times, strengthen e-government efforts to form adaptation "Internet + " development of ideas and understanding.

\subsection{To encourage innovation}

"Internet +" era as a new economic and social forms, should be fully recognized and encouraged, car model as a form of expression, a total ban is clearly not meet the social development approach. Internet + The "+", not just technically, "+", is thinking, "+" concept, schema.

\subsection{Strengthen supervision, to achieve an orderly innovation}

Car model is a business based on mobile Internet platform, it should be a combination of traffic and Internet business, that is, "the integration of the business." The method adopted for taxi management in the past is the traffic regulation, but now mingled with a variety of business, resulting in the body will blend. So in the regulatory process should be the regulatory body for each simultaneously. Internet car model innovation should be encouraged, but there is still a lack of a clear definition of this. Therefore, the relevant departments as soon as possible from a legal definition of this conduct, for a rental car operating qualified car business in the Internet business practices, but also to be identified in the law, while the introduction of appropriate management practices and tariff guide, so that formed with the existing taxi operators benign complementary, rather than vicious competition.

\subsection{How to adjust the original policy}

Change the original taxi management policy has been unable to adapt to the taxi business model at this stage, the government should amend the city's local laws or enact regulations to provide a basis for normal car, clearly a legitimate form of its existence, space. But also improve the car insurance system, defuse the risk of accident compensation, compulsory car purchase third-party liability insurance, and establish complaint channels.

\section{Conclusion}

We should respect the choice of the market, the taxi software existing because they have the market. The government should not be completely banned. The market can bring benefit; the development of cost-effective can protect public 
welfare. The government should not avoid the problem by banning, but to actively respond to challenges, take a cooperative attitude, use of the Internet to strengthen the management of vehicles and information. Use market efficiency to increase social benefits. Use information technology so that people can be more convenient access to services. Managers must constantly adapt to the new situation and changes and new requirements of the network society. The government can know the need of people through the network and the internet can make people easy to participate in management. We can final form a feedback and decision-making and supervision system.

\section{Acknowledgements}

I would like to extend my sincere gratitude to my Master Instructor Kai Yu, for his instructive advice and useful suggestions on my thesis. I am also deeply indebted to all the other tutors and teachers in translation studies for their direct and indirect help to me. Finally, I am indebted to my parents for their continuous support and encouragement.

\section{References}

Cao, Y., \& Luo, X. (2014). Taxi service speed analysis based on the taxi software usage [J]. Chongqing Jiaotong University (Natural Science).

Cao, Y., \& Luo, X. (2015). Under software background taxi empty driving industry forecast model [J]. Wuhan University of Technology (Transportation Science \& Engineering Edition), 1, 51-54.

Deng, W. L. (2007). Virtual Internet Information Age to strengthen social management thinking[J]. Public security research, 2, 78-81.

Hui, X. Y., \& He, L. K. (2011). Public participate innovation in Social management in the Internet environment[J]. e-government, 9, 48-54.

Jiang, S. Y. (2012). The Internet and Social Management Practice Innovation[J]. Theoretical magazine, 1, 163-165.

Li, N. (2013). Innovation of Social Management of the Information Age[D]. East China Normal University.

Liu, C. R. (2011). Shanghai Taxi integration tide [J]. Shanghai State-owned, 6, 42-43.

Newspaper Reporter (2015). Internet car Do not rush qualitative "black car"[N]. Legal Daily, 01-06006.

Newspaper reporter Lin Lin(2015). Ministry of Transportation for the car black and white set the tone of the dispute Forced interests of the game of competitive differentiation [N]. Communication information reported, 01-14A04.

Sun, A. D. (2015). Taxi management department, please do not fall behind in this era[J]. Exploration(first half),02:11.

Sun, J. X. (2015).Taxi industry in the Internet[J]. China information, 6, 23.

Yan, J. (2015). Uber the "Internet +" thinking Optimizing Hangzhou traffic service environment[J]. Financial Sector, 6, 98-101.

Yang, F. F. (2014).Thoughts on management reform Hangzhou taxi operators[J]. Modern City, 3, 36-39.

Yuan, G. X., Pan, J., \& Ma, X. (2014). Mobile Internet security challenges and countermeasures[J]. Internet World, 3, 21-25.

Zhang, S. Q., \& Lu, W. Q. (2013). Social management innovation network Era[J]. Theory, 31, 113-114.

Zheng, Y. Y. (2015). Internet + taxi, how to define innovation[N]. Rural Financial Times, 06-08003.

Zhu, K. (2012). Reflections on the Internet era of social management innovation[J]. Chifeng University (Natural Science), 16, 18-19.

Zhu, W. L. (2011). How to manage the internet of innovation[J]. Mangers, 2, 84-85.

Zong, K. (2015). Next two years focused on creating the "Internet + Urban Transport" in Tianjin[N]. Science and Technology Daily, 03-23011.

\section{(cc) EY}

This work is licensed under a Creative Commons Attribution 3.0 License. 